\title{
A Comparison of the Efficacy of an Alpha-I-Adrenergic Blocker in the Slow Calcium Channel Blocker in the Control of Autonomic Dysreflexia ${ }^{\star}$
}

Rosemary Lindan, M.B., B.S., ${ }^{1}$ Elizabeth J. Leffler, R.N. ${ }^{1}$ and K. R. Kedia, M.D. ${ }^{2}$

${ }^{1}$ Spinal Cord Injury Center, Highland View Hospital, ${ }^{2}$ Department of Urology, Cleveland Metropolitan General Hospital, 3395 Scranton Road, Cleveland, Ohio 44109, U.S.A.

\begin{abstract}
Summary
Cystometry, using a portable $\mathrm{CO}_{2}$ cystometer, is a convenient method for detecting autonomic dysreflexia (A.D.) in response to bladder distention. Serial tracings on successive days were found to be consistent. This method was used to compare the effect of the antihypertensive drugs, phenoxybenzamine and nifedipine, in modifying the blood pressure responses of 12 tetraplegic patients. Given as regular medication twice daily, neither drug was effective in preventing A.D. responses to bladder filling, and a significant number of patients developed troublesome hypotension. Nifedipine by mouth was found to be a valuable drug for the treatment of attacks which developed, and capable of preventing an anticipated attack if given shortly before the stimulus. The condition of 'status dysreflexicus' and its appropriate management is described.
\end{abstract}

Key words: Tetraplegia; Autonomic dysreflexia; Phenoxybenzamine; Nifedipine; $\mathrm{CO}_{2}$ cystometry.

\section{Introduction}

Autonomic dysreflexia (A.D.) is a troublesome complication of the rehabilitation of some spinal cord injury patients. In our unit we have been concerned with the practical aspects of the prevention and treatment of this condition.

In a retrospective clinical study, which we did in 1979, we came to the conclusion that the antihypertensive drugs which we were using at that time, hydralazine and phenoxybenzamine, did not appear to be effective in preventing chronic attacks and suggested that a controlled prospective study needed to be done (Lindan et al., 1980). The only way to do a controlled study of this condition is to use the patient as his or her own control, because of the variability of response to the same stimulus from patient to patient. The reproducibility of

${ }^{\star}$ Read at the Scientific Meeting of the International Medical Society of Paraplegia in Denver, Colorado, U.S.A., June 1984. 


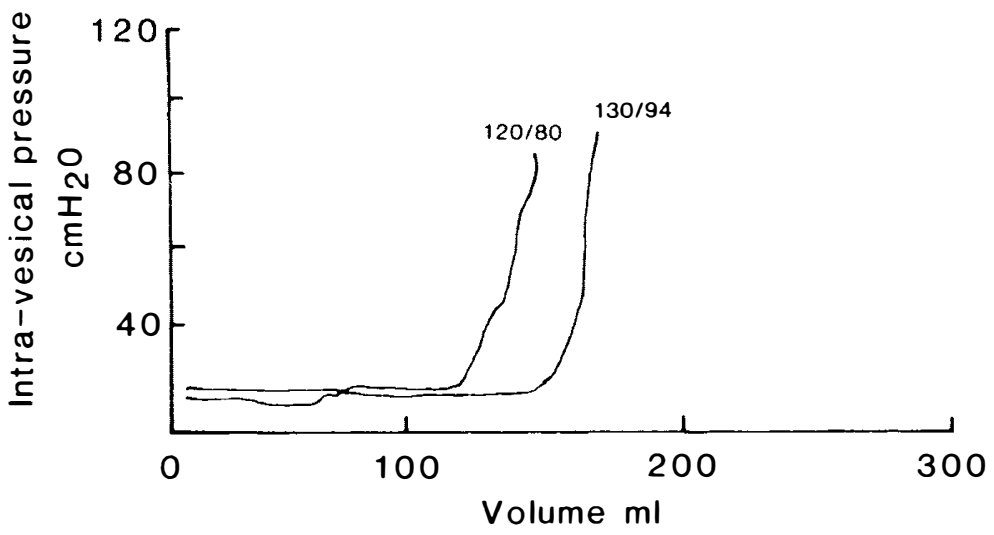

Figure 1. $\mathrm{CO}_{2}$ Cystometric tracings on patient A.J. (C6-Complete) to show reproducibility of tracings. Starting BP on $9 / 29-120 / 80$, on $9 / 30-130 / 90$.

carbon dioxide $\left(\mathrm{CO}_{2}\right)$ cystometric tracings in the individual patient suggested that this technique might be useful for our purpose. The cystometer which we use is a small unit which can be brought to the patient's bedside, and the whole procedure does not take more than 10 to 15 minutes. Figure 1 shows an example of the tracing obtained on two successive days from a tetraplegic man, who was voiding reflexly and it can be seen that the tracings are almost identical.

Using this technique, we have attempted to compare the effectiveness of the alpha adrenergic blocker phenoxybenzamine with a newer drug, nifedipine, in the prevention of A.D. precipitated by distention of the urinary bladder.

Phenoxybenzamine has been specifically advocated for the prevention of A.D. (Scott and Morrow, 1978) but it is now known to have carcinogenic potential with long term use, and it may possibly be withdrawn from the market. It therefore seemed prudent to look for an alternative drug with a different type of action. Nifedipine is a relatively new drug, originally marketed for the treatment of coronary angina but now being used for a variety of conditions characterised by smooth muscle spasms (Corris, Nariman and Gobson, 1983; Mondero, 1983; Rudd, Anderson and Ulmsten, 1979; Zar and Gooptu, 1983).

Both of these drugs act by preventing constriction of arteriolar smooth muscle but their mechanisms of action are quite different. Phenoxybenzamine blocks the sympathetic stimulus at the receptor site. It is slow to take effect and has a relatively long half life. Nifedipine prevents the entry into the muscle cells of calcium ions necessary for contraction. It is a rapid acting drug with a short half life.

\section{Patients and methods}

Twelve patients, ten men and two women, with cervical cord injuries (Table 1) were studied by serial $\mathrm{CO}_{2}$ cystometric tracings. A base line tracing with the patient on no medications was followed by tracings with the patient on phenoxybenzamine, $10 \mathrm{mg}$ b.i.d. and then on nifedipine, $20 \mathrm{mg}$ b.i.d. Cystometry was usually performed in the early afternoon.

During the cystometric testing, the patient's blood pressure was taken at 
Table 1 Composition and characteristics of patient study group

\begin{tabular}{cccccc}
\hline $\begin{array}{l}\text { No. of } \\
\text { points }\end{array}$ & Male & Female & $\begin{array}{c}\text { Age in } \\
\text { years }\end{array}$ & $\begin{array}{c}\text { Level of } \\
\text { injury }\end{array}$ & $\begin{array}{c}\text { Months after } \\
\text { injury }\end{array}$ \\
\hline 12 & 10 & 2 & $\begin{array}{c}19-54 \\
\text { (mean 30) }\end{array}$ & $\begin{array}{c}\text { C } \\
4-6\end{array}$ & $\begin{array}{c}5-16 \\
\text { (mean 9) }\end{array}$ \\
\hline
\end{tabular}

$50 \mathrm{ml}$ increments of $\mathrm{CO}_{2}$, and the test was terminated when the blood pressure rose to $\geqslant 140 / 90$ or the patient exhibited symptoms, or the intravesical pressure rose to voiding level.

In 11 additional patients the effectiveness of nifedipine in treating or aborting A.D. attacks was also investigated. Seven patients who developed A.D. attacks in the ward were given $10 \mathrm{mg}$ of nifedipine by mouth and their blood pressure monitored at 5 to 10 minute intervals until it had returned to normal. Four other patients who were known to be susceptible to A.D. and who were scheduled for procedures which could be expected to trigger an attack (e.g., cystoscopy or cystogram), were given $10 \mathrm{mg}$ of nifedipine by mouth 30 minutes before the procedure was to begin.

\section{Results}

The serial cystometric tracings obtained on 12 patients while on phenoxybenzamine for 4 or more days showed that the blood pressure still rose with bladder distension in ten patients and remained at the base level in only two patients. In the ten patients who were given nifedipine on a regular daily basis for 24 hours or more, eight still showed a rise in blood pressure with bladder distension, and in two the blood pressure did not rise. It can be seen from the tracings that administration of both drugs resulted in a reduction of the 'resting' blood pressures, so that the final blood pressure readings were proportionally lower with drugs than without (Figs. 2 and 3). In fact, four of the patients on regular dosage of phenoxybenzamine and three on nifedipine developed hypotensive symptoms which were severe enough to necessitate reduction or discontinuation of the drugs.

Incidents of acute A.D. precipitated by noxious stimuli other than bladder distension, such as infections, bladder calculi, and sphincter dyssynergia still occurred in patients on both of the drug regimens. The blood pressures developed and symptoms occurring in these attacks did not seem different from those experienced when the patients were on no drugs.

We did find, however, that acute attacks could be readily controlled by giving the patient $10 \mathrm{mg}$ of nifedipine by mouth. In the seven patients so treated, the blood pressure started to drop within 5 to 10 minutes and had returned to near normal within 30 to 40 minutes. None of the four patients given prophylactic nifedipine before a challenging manipulation developed A.D.

While doing these studies we observed three incidents of what can aptly be described as 'status dysreflexicus,' an expression coined by Dr Arnold GrahamSmith, as we discussed one of his cases. Typically, a susceptible patient develops a severe attack of A.D. which subsides initially when the cause is removed. In the ensuing 7-10 days however, any stimulus, no matter how slight will cause another attack. During this period of enhanced sensitivity, in addition to giving 


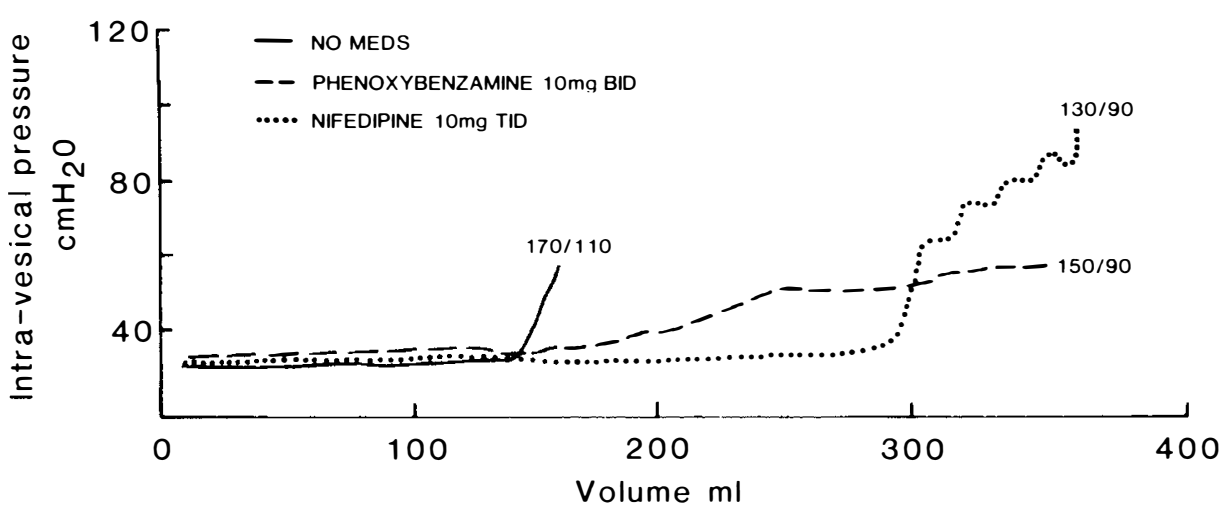

Figure 2. $\mathrm{CO}_{2}$ Cystometric tracings on patient M.R. (C6-Complete). Starting BP-No Meds 150/90 Phenoxybenzamine 120/80 Nifedipine 108/70.

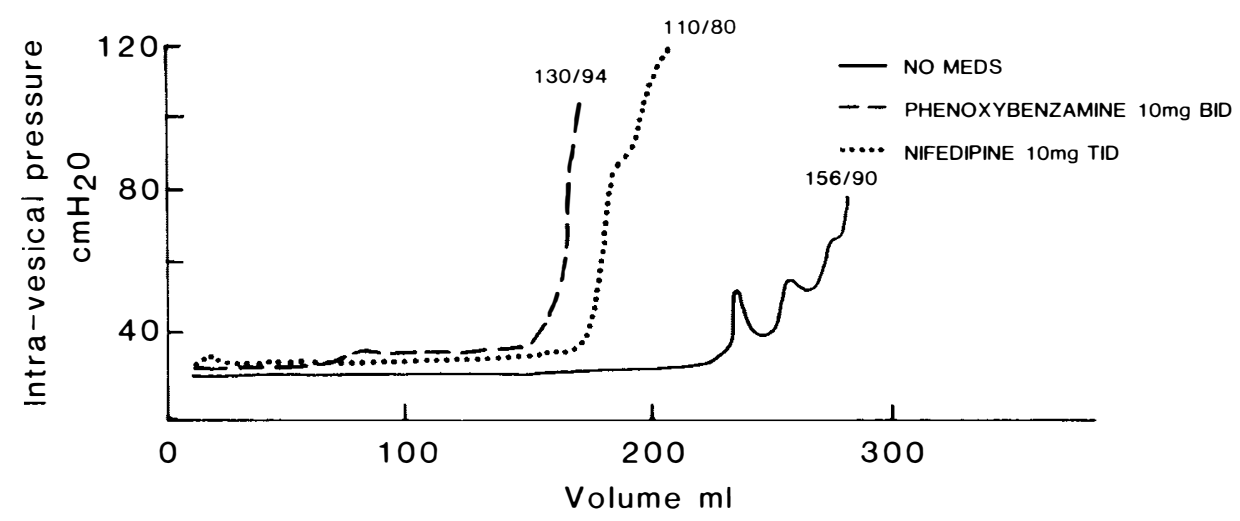

Figure 3. $\mathrm{CO}_{2}$ Cystometric tracings on patient A.J. Starting BP-No Meds 140/80 Phenoxybenzamine 130/90 Nifedipine 100/60.

$10 \mathrm{mg}$ nifedipine by mouth for each blood pressure rise above 140 systolic/90 diastolic, the patient is maintained in the reverse Trendelenburg position and is kept completely quiet except for a hot shower daily. The catheter is neither changed nor irrigated, and bowel routines are performed only with great care and with the liberal use of anaesthetic lubricant. Status dysreflexicus is not a new phenomenon and retrospectively we can identify approximately 18 more cases which have occurred in our unit prior to the present study. It is important to be aware of this type of prolonged A.D. response, so that manipulations are kept to a minimum and continuing attempts are not made to find other causes for the repeated attacks, by energetic examinations of the lower bowel for example.

\section{Conclusions}

From these studies we have reached the following conclusions:

1. Regular daily dosage with phenoxybenzamine or nifedipine will not prevent attacks of A.D. from occurring in the majority of susceptible patients, and 
frequently results in troublesome hypotension.

2. Nifedipine, in doses of $10 \mathrm{mg}$ by mouth, is indicated however for the treatment of acute A.D. attacks. It is easily administered, can be used as self medication by the patient and it acts within 15-30 minutes.

3. Nifedipine, $10 \mathrm{mg}$ either sublingually or by mouth can be given prophylactically 30 minutes prior to a scheduled procedure which is expected to cause A.D. in a susceptible patient, and will effectively abort an attack.

4. 'Status dysreflexicus,' which is seen in approximately three per cent of recently injured quadriplegics, should be treated by giving $10 \mathrm{mg}$ of nifedipine by mouth for each blood pressure rise, every 6 hours if needed, and avoidance of all stimuli until the condition subsides, usually in 7 to 10 days.

\section{Résumé}

La cystométrie, à l'aide d'un cystomètre portatif à $\mathrm{CO}_{2}$, est une méthode commode de détecter la dysréflexie automome (A.D.) en réponse à la distension de la vessie. On a trouvé que des tracés de série exécutés plusieurs jours de suite s'accordaient bien. On a employé catte méthode pour comparer l'effet des drogues antihypertensives, phénoxybenzamine et nifédipine, dans la modification des réponses de tension artérielle chez 12 malades tétraplégiques. Administrée comme médication régulière deux fois par jour, ni l'une ni l'autre de ces drogues n'était effective dans la prévention des réponses A.D. au remplissement de la vessie, et un nombre significatif de malades a développé une hypotension gênante. On a trouvé que la nifédipine administrée oralement était une drogue de valeur pour le traitement des attaques qui se développaient, et qu'elle était à même d'empêcher une attaque anticipée si on l'administrait peu avant le stimule. On décrit la condition de 'status dysreflexicus' et son traitement approprié.

\section{Zusammenfassung}

Die Zystometrie, mittels eines tragbaren $\mathrm{CO}_{2}$-Zystometers, ist eine bequemliche Methode daf ür, autonome Dysreflexie (A.D.) in Antwort auf Blasendistention zu entdecken. Man hat gefunden, dass an nachfolgenden Tagen ausgef ührte Serienaufzeichnungen im Einklang sind. Man hat zwar diese Methode angewendet, um die Wirkung der Antihypertensionsdrogen, Phenobenzamin und Nifedipin, in der Abänderung der Blutdruckantworten von 12 tetraplegischen Patienten zu vergleichen. Als regelmässiges Heilmittel zweimal pro Tag gegeben, hat keine von diesen Drogen sich wirksam in der Verhinderung der A.D.-Antworten auf die Blasenf üllung bewiesen, und eine bedeutende Anzahl Patienten hat beschwerliche Hypotension entwickelt. Man hat gefunden, dass das oral gegebene Nifedipin eine wertvolle Droge für die Behandlung von Anfällen, die sich entwickelten, ist, und weiter dass es imstande ist, einen vorausgeahnten Anf all zu verhindern, wenn nur man es kurz vor dam Reiz gibt. Man beschreibt den Stand des 'Status dysreflexicus' und seine zweckmässige Behandlung.

\section{References}

Corris PA, NARIman S, Gibson GJ 1983 Nifedipine in the prevention of asthma induced by exercise and histamine. American Review of Respiratory Disease 128:991-992.

Lindan R, Jonier E, Freehafer AA, HAZel C 1980 Incidence and clinical features of autonomic dysreflexia in patients with spinal cord injury. Paraplegia 18:285-292.

MONDERo NA 1983 Nifedipine in the treatment of dysmenorrhea. Journal of the American Osteopathic Association 82: (9 Suppl.): 704-708.

RuDD T, ANDERSSON K, UlMSTEN E 1979 Effects of nifedipine in women with unstable bladders. Urologia Internationalis 34:421-429.

SCOTT MB, MORROW JW 1978 Phenoxybenzamine in neurogenic bladder dysfunction after spinal cord injury. II Autonomic Dysreflexia. Journal of Urology 119:483-484.

ZAR MA, GOOPTU D 1983 Effect of nifedipine on the contractile responses of human colonic muscle. British Journal of Clinical Pharmacology 16:339-340. 